\title{
Geochemical Exploration for Gold and the Association of As-Cu-Pb-Sn-Zn-Li in the Upper Proterozoic Granitoids of the Wadi Rumman Area, Southwest Jordan
}

\author{
Ibrahim Ahmad Ali Bany Yaseen \\ Institute of Earth and Environmental Sciences, Al-al-Bayt University, \\ Al-Mafraq, Jordan \\ Email: ibanyyaseen@yahoo.com
}

Received 14 September 2015; accepted 26 October 2015; published 29 October 2015

Copyright (C) 2015 by author and Scientific Research Publishing Inc. This work is licensed under the Creative Commons Attribution International License (CC BY). http://creativecommons.org/licenses/by/4.0/

\section{Abstract}

The geochemical studies were conducted in an area covering about $15 \mathrm{~km}^{2}$ of the south side of the Wadi Rumman area, SW Jordan. The study area included a part of a basement of complex exposed rocks in southwestern Jordan. The complexes comprised igneous and metamorphic suites, mostly from the late Proterozoic age. A systematic geochemical sampling was conducted using rock and heavy mineral-panned concentrate of geochemical samples. Fifty rock samples were collected from the granitic rocks, simple pegmatite dyke, quartz veins and alteration zone, which covered the area. Next, 45 heavy mineral-panned concentrate samples were collected from the alluvium in the stream sediment within the catchment area, and the dray was sieved to less than $1 \mathrm{~mm}$ grain size. The geochemical samples were analyzed for their trace elements and gold by using Ione Conductive Coupled Plasma Emission Spectroscopy (ICP-AES) and the Atomic Absorption Spectrometer (AAS) at Natural Resources Authority (NRA) Labs. The results of the geochemical analysis indicated the presence of gold and heavy minerals in the study area, a result considered abnormal in the rock samples. A strong positive correlation was recorded of Au with $\mathrm{As}, \mathrm{Cu}$ and $\mathrm{W}(\mathrm{r}=$ $0.82,0.7$ and 1.0), as with Mo $(r=0.83)$, Cu with $\mathrm{Pb}(\mathrm{r}=0.83)$, Sn with Mo $(r=0.73)$, Mo with $W(r=$ $0.97)$, $\mathrm{Zn}$ with $\mathrm{W}(\mathrm{r}=\mathbf{0 . 7 1})$, and $\mathrm{Li}$ with $\mathrm{Bi}(\mathrm{r}=0.7)$. These correlations revealed gold associated within the hydrothermal alteration, quartz veins and pegmatite dyke. Abnormal metals such as As and Bi were good path-finders to find $\mathrm{Au}$. The HM samples showed low positive linear correlations among the concentrations of $\mathrm{Au}$ with $\mathrm{As}, \mathrm{Zn}$ and $\mathrm{Li}$, and negative linear correlations of $\mathrm{Au}$ with $\mathrm{Pb}$, $\mathrm{Sn}, \mathrm{Bi}$ and $\mathrm{W}$. The combination of both rock and heavy mineral concentrate samples shows four geochemical anomalous areas of gold and heavy minerals. The geochemical signatures of $\mathrm{Au}$ and As in the Wadi Rumman appear to be in the hydrothermal alteration, quartz veins and pegmatite 
dyke, respectively. Heavy mineral concentration sampling delineated the Au geochemical anomaly in area 1 specificities with the rock geochemical anomaly of area 1.

\title{
Keywords
}

\author{
Geochemical Exploration, Granitoids, Rock and Heavy Mineral Samples, Wadi Rumman, Jordan
}

\section{Introduction}

Geochemical prospecting for minerals includes any method of mineral exploration based on the systematic measurement of one or more chemical properties of the naturally occurring materials. The chemical property measured is most commonly the trace content of some element or group of elements. The reason for recording these measurements is to discover abnormal chemical patterns or geochemical anomalies, related to mineralization. Among the several geochemical prospecting methods used to discover the study area, the heavy minerals and rock geochemical exploration methods were selected and used in the study area, as they were the more effective methods suitable for this type of region. Heavy mineral geochemical samples of less than $1 \mathrm{~mm}$ grain size were collected from the alluvium in the stream sediment, which were a useful method of verifying any decision made during the geochemical exploration for minerals, including the transport distance of the gold nuggets and ultimately regarding the origin of the element dispersion halo [1]. The fine fraction method is usually used in geochemical exploration, because of the small grain size, which makes it possible to use a small sample weight and to some extent eliminate the reduction and secondary sub sampling errors. For exploration mineralogists, the key problems arise from the low concentration thresholds of gold anomalies and the small particle size [1]. Rock geochemical samples used to collect the composite sample. The objective of this study was to undertake a geochemical exploration for minerals in the plutonic rocks, which covered the area under study, in an attempt to identify the areas of geochemical anomalies for $\mathrm{Au}, \mathrm{As}, \mathrm{Cu}, \mathrm{Pb}, \mathrm{Sn}, \mathrm{Mo}, \mathrm{Bi}, \mathrm{W}, \mathrm{Zn}$ and $\mathrm{Li}$. It was also done to identify the possible presence of the ore minerals in the target areas by using the rock and heavy mineral geochemical exploration methods.

\section{Geological Setting}

The basement rocks exposed in southwestern Jordan are subdivided into two broad lithostratigraphic complexes, the Aqaba and Araba [2]-[5]. These complexes comprise the igneous and metamorphic suites, mostly of the late Proterozoic age. These complexes are separated by a regional unconformity (peneplanation), represented by the Saramuj Conglomerate Formation [6] [7]. The Aqaba complex (800 to 570 Ma) includes the metamorphic and intrusive calc-alkaline plutonic and metamorphic rocks. The Araba complex (625 - $600 \mathrm{Ma}$ ), on the other hand, consists of the Safi and Feinan granitic suite, and Qirenifat and Ahaymir volcanic suites [8]. The area under study is included within the Aqaba complex and the outcropping from the late Proterozoic calc alkaline granitoids the Rumman and Yutum suite, such as Ishaar granite, Qara granite and Rashidiyya Aplite granite, respectively. The granitites are cross-cut by numerous dykes of varying composition (from acidic to basic) and thin quartz veins and an alteration zone. The lower Paleozoic sedimentary rocks for the Ram Sandstone group include Salib Arkoze Sandstone and Umm Ishrin Sandstone which are unconformable and overlaid Proterozoic igneous rocks [9] [10]. The area under study is located at $35^{\circ} 15^{\prime} 727^{\prime \prime E}-35^{\circ} 15^{\prime} 730 " \mathrm{E}$ and $29^{\circ} 30^{\prime} 3271 \mathrm{~N}$ $29^{\circ} 30^{\prime} 3275 " \mathrm{~N}$ covering about $15 \mathrm{~km}^{2}$. The geological units are described as follows:

The Qara granite unit contains medium- to coarse-grained, pink- to whitish-pink to light grayish-pink syenogranite to monzogranite. The mesocratic rocks include small mafic clots at the outcrop, highly weathered and cut by dense dykes of rhyolite and quartz veins. The main mineral composition includes quartz, alkali feldspar and biotite with traces of hornblende and phaneritic in texture, particularly along the margins of the zone in contact with the Ishaar unit. Ishaar granite is medium to coarse grained, phaneritic in texture, grey to greenishgrey, which varies according to the granodiorite. Mesocratic, small circular mafic clots with biotite and hornblende are common, cut by dykes of variable compositions of rhyolite, pegmatite and quartz vines. Quartz, alkali feldspar and biotite constitute the main mineral composition. Rashidiyya Aplite Granite is distinguished by fine grain size, micro granite, pink to whitish-pink colors, leucocratic and sugary with aplitic texture. Acidic 
dykes and thin quartz veins cut through this unit. Quartz alkali feldspar and biotite form the main mineral composition. Salib Arkosic Sandstone Formation, Early Cambrian in age, consists predominantly of yellow, pink, and purple-brown colors, with very coarse- to medium-grained, cross-bedded arkosic and subarkosic sandstone; pebbles to cobble conglomerates are also locally present. Rounded to sub-rounded pebbles of milky-white quartz and pink feldspar are also seen. Umm Ishrin Sandstone Formation includes the middle to late Cambrian age, with brown, red-brown to yellowish-pink and grey colors, of medium to coarse-grained quartz arenite, with rounded granules and quartz pebbles. There are thin beds of fine-grained sandstone and siltstone exhibiting lineation. Secondary ferruginous and manganese ferrous show color banding and oxides with a massive-weathering face and the typical large trough cross-bedding with pebbles, occasionally overturned for sets is common. Angular clastic siltstone in locally eroded channels is evident, close to the gradational upper boundary of the formation; Figure 1 shows the geological map of the area of study.

The geologic structures of the area under study are affected by the tectonic activity that occurred during the late Proterozoic to the early Cambrian for the extension of the Arabian-Nubian shield which plunges to south Jordan [11] [12]. The early Paleozoic rocks of the Aqaba and Araba complexes of the Precambrian basement are affected by the northwest striking faults and tension joints. The NN-SSW faults, parallel to the rift, extend south into Saudi Arabia, where normal faulting and sinistral strike-slip movements can be demonstrated [13]. Major faults within the Aqaba complex are oriented to the north-northeast $\left(0^{\circ}-15^{\circ}\right)$ trend, revealed by the extensive Wadi Rumman and Wadi Rum faults. The areas of study (Wadi Rumman) affected by these faults, have recorded 300 - $450 \mathrm{~m}$ westerly downthrows and 4 - $5 \mathrm{~km}$ sinistral lateral displacement [10]. The principal and subsidiary joints are shown in the various study units, in the E-W, ENE-WSW, and in the NE-SW directions for the study of the granitoid units and the NW-SE, N-S and E-W trends in the direction shown for the Salib and Umm Ishrin formations.

\section{Sampling and Analytical Techniques}

Two geochemical methods of investigating rocks and heavy minerals were used in the geochemical exploration of the area under study. Sample points were selected from a published 1:50,000 scale topographic and geological map.

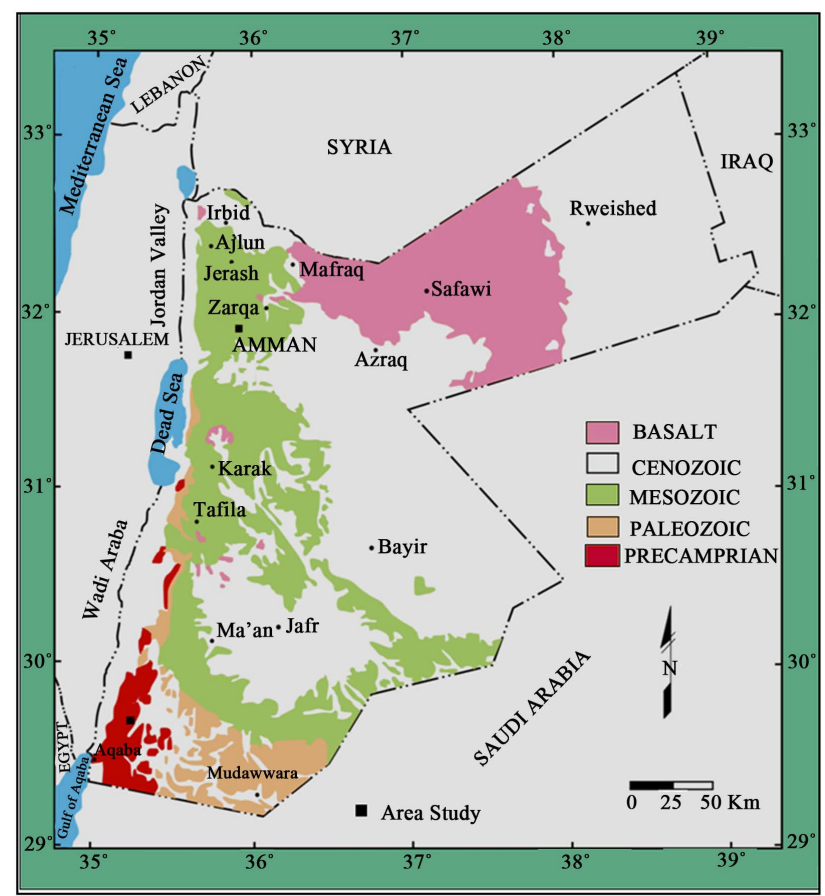

(a)

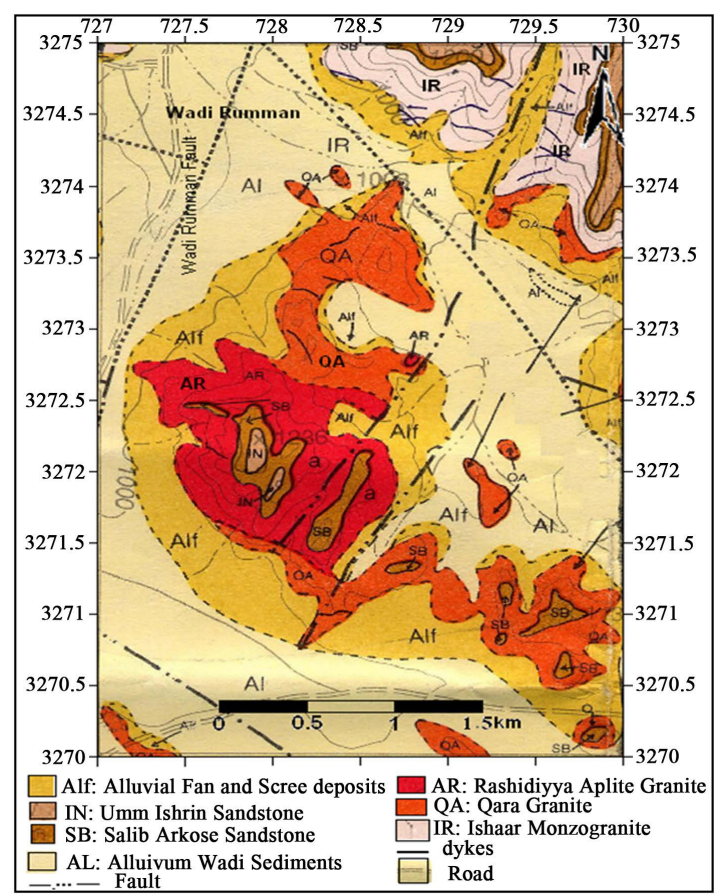

(b)

Figure 1. (a) Simplified Geological map of Jordan show the Area study after [15]; (b) Geological map of the area under study after [9]. 
Fifty rock chip samples were collected from the outcropping of the granitic rocks, simple pegmatite, dyke, quartz veins and alteration zone, at a density of five samples per $1 \mathrm{~km}^{2}$ (Figure 2(a)). The lithology, quartz veins and alteration intensity of the rocks were studied in the field under natural light using high magnification lenses. Thin sections were then prepared and detailed mineralogical and alteration features were studied under the petrographic microscope. The samples crushed and powdered using a stainless steel Jaw Crusher and an Agate Ball Mill machine, to obtain grain size less than $-63 \mu$. The samples were quartered in order to get a statistically representative (splitter) fraction and powdered using two geochemical techniques at the Natural Resources Authority (NRA) labs.

Forty-five heavy mineral concentrated samples were collected from the alluvium in the stream sediment within the catchment area of the study, at a density of four samples per $1 \mathrm{Km}^{2}$ (Figure 2(b)). Then dry stainless steel sieving was performed at the sampling site to get about $4 \mathrm{~L}$ by volume of alluvium, of grain size less than $1 \mathrm{~mm}$. The samples were then placed in $8 \mathrm{~L}$ stainless-steel pans, and washed in sea-water close to Aqaba to eliminate material by the law of specific gravity and collect a resultant of about $200 \mathrm{~g}$ of heavy mineral concentrates. The concentrates were rinsed thoroughly in fresh water, placed on plates and sun dried.

\section{Analytical Techniques}

The trace elements were analyzed by decomposition using Ione Inductively Conductive Coupled Plasma Emission Spectroscopy (ICP-AES) at Natural Resources Authority Labs. A total of $1 \mathrm{~g}$ of the powdered ( $<80$ mesh) sample mixed with $3 \mathrm{~g}$ of sodium peroxide $\left(\mathrm{Na}_{2} \mathrm{O}_{2}\right)$ were placed in a zirconium crucible, and fused by heating it to $450^{\circ} \mathrm{C}$ for $45 \mathrm{mints}$, to obtain a sinter. Subsequently, $72 \mathrm{ml}$ of deionized water was added to it and stirred for a few mints; then $28 \mathrm{ml}$ of diluted $\mathrm{HCl}$ in a ratio 1:1 was added to obtain clear solutions that were used to determine the trace element concentrations.

The Atomic Absorption Spectrometer (AAS), PerkinElmer 3030 Model was used for gold analysis in the Natural Resources Authority Labs. The analytical method consisted of dissolving the Au in the sample by heating with aqua regia solution ( $3 \mathrm{ml}$ conc. $\mathrm{HCl}+1 \mathrm{ml}$ conc. $\mathrm{HNO}_{3}$ ) plus iron. The gold (Au) was then extracted with methyl isobutyl ketone (MIBK) solution by introducing the organic phase into a pyrocoated graphite furnace and then analyzed for gold using the Atomic Absorption Spectrometer [14]. The gold concentration was expressed in parts per billion (ppb). The lower detection limit of this analysis method was (10 parts per billion (ppb). Excel 2007 and Surfer 8 were used to perform statistical analyses of the data.

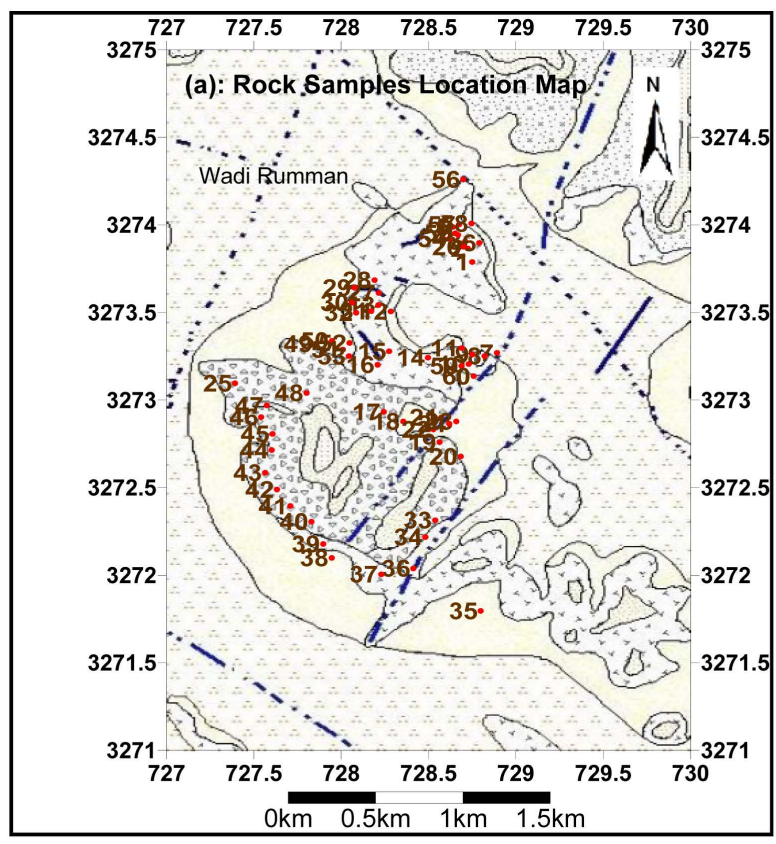

(a)

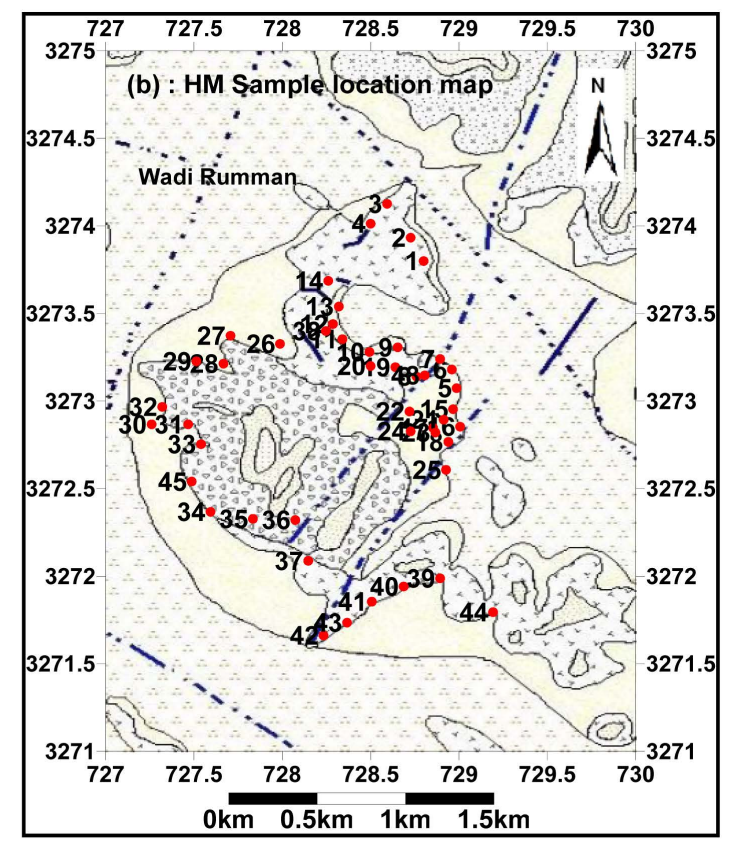

(b)

Figure 2. (a) Rock sample location map; (b) Heavy mineral sample location map. 
The mineral composition identified by using the petrographic microscope and X-ray Diffraction (XRD) by employing a Philips diffractometer with $\mathrm{Cu}$ Ka radiation, at the University of $\mathrm{Al}$ al-Bayt.

\section{Results and Discussion}

\subsection{Petrography and Mineralogy}

The rock samples study showed leucocratic, holocrystalline and hypidiomorphic to allotriomorphic fine- to medium-sized grains, phaneritic to megaprophyritic in texture. Using the polarizer microscope and XRD, quartz, feldspar, biotite, hornblende and opaque minerals such as iron oxide and magnetite, were the main minerals identified. The secondary minerals included calcite, sericite, kaolinite and chlorite while the rare minerals found were wolframite (W), davite (B) and cassiterite (Sn). The common textures of the rock samples in the study were perthitic, poikilitic interstitial, zoning and polysynthetic twinning. The lithology and petrography of the area under study showed an alteration zone with high concentration of secondary and oxide minerals. These were indications of the mineralization ore minerals which were documented by chemical analysis for gold and the pathfinders for the geochemical association of the elements. The lithology and petrography are summarized in Table 1.

\subsection{Rock Geochemistry}

The earlier regional geochemical survey of the rocks of the Upper Proterozoic (Aqaba and Araba complexes) in southwest Jordan had been conducted for the regional geochemical survey project [15]. The average concentrations (ppm) of the trace elements in the Aqaba and Araba complexes, that comprise the igneous and metamorphic suites, mostly of the late Proterozoic age were reported by [15], as $10 \mathrm{mg} / \mathrm{ton}$ for Au, $15 \mathrm{ppm}$ for As, 20 ppm for Cu, 15 ppm for Pb, 7 ppm for Sn, 5 ppm for Mo, 9 ppm for Bi, 6 ppm for W, 5 ppm for Zn and 5 ppm for Li. According to [16], the epithermal gold mineralization investigated in the Wadi Abu Khushayba within the calc-alkaline granitic rocks includes the late Proterozoic rocks within the Araba complex. The area under study includes the Aqaba complex and outcropping of the late Proterozoic calc alkaline granitoids.

The trace background values of the study area were taken as the mean and median values [17], as shown in Table 2(a). In fact, [18] suggested that the background could be used as the median. The separation between the background and anomalous values were defined using the classical statistical treatment with the threshold calculation from the mean and median plus two standard deviations (SD) [19]. The results from the data for the area of study were treated with statistically cumulative frequency plots. The statistical calculations for the area were more or less similar reflecting the search for a similar target lithology. The statistical treatment of the rock data resulted in the adoption of two threshold values (Threshold $1=$ mean +2 SD) and (Threshold $2=$ median + $2 \mathrm{SD}$ ) respectively, and the background values were equal to the mean value. The data below the value of the detection limits were assumed as the minimum value of the analyzed element and the statistical parameters were then computed on this assumption and the maps of geochemical anomalies, Figure 3. Thresholds 1 and 2 for Au equal 44 \& 38.6, As 26.98 \& 25.28, Cu 97.03 \& 79.4, Pb 73.23 \& 75.6, Sn 82.86 \& 68.66, Mo 48.8 \& 42, Bi 8.9 \& 7.8, W 34.1 \& 30.4, Zn 153.08 \& 138.28 and Li 184.4 \& 159.84, respectively (Table 2(a)).

The Pearson's correlation coefficients from among the concentrations of $\mathrm{Au}, \mathrm{As}, \mathrm{Cu}, \mathrm{Pb}, \mathrm{Sn}, \mathrm{Mo}, \mathrm{Bi}, \mathrm{W}, \mathrm{Zn}$ and $\mathrm{Li}$ found in the study of the rock samples are presented in Table 2(b). Low positive linear correlations among the concentrations of $\mathrm{Au}, \mathrm{Zn}, \mathrm{As}, \mathrm{Sn}, \mathrm{Cu}, \mathrm{Pb}, \mathrm{Sn}, \mathrm{Mo}, \mathrm{Li}$ and Bi were clearly observed: Au with $\mathrm{Zn}(\mathrm{r}=$ $0.06)$, As with $\mathrm{Sn}(\mathrm{r}=0.16)$, Cu with $\mathrm{Sn}(\mathrm{r}=0.1)$, Cu with $\mathrm{Zn}(\mathrm{r}=0.03)$, Pb with $\mathrm{Zn}(\mathrm{r}=0.34)$, Sn with $\mathrm{Zn}$, Li, $\mathrm{Bi}$ and $\mathrm{W}(\mathrm{r}=0.27,0.2,0.17$ and 0.032 , respectively), Mo with $\mathrm{Zn}(\mathrm{r}=0.01) \mathrm{Zn}$ with $\mathrm{Li}$ and $\mathrm{Bi}(\mathrm{r}=0.4$ and 0.1$)$. Strong, positive correlation of Au with As, $\mathrm{Cu}$ and $\mathrm{W}(\mathrm{r}=0.82,0.7$ and 1.0), As with $\mathrm{Mo}(\mathrm{r}=0.83)$, Cu with $\mathrm{Pb}$ $(r=0.83)$, Sn with Mo $(r=0.73)$, Mo with $W(r=0.97)$, Zn with $W(r=0.71)$, Li with Bi $(r=0.7)$, these correlations revealed that the hydrothermal alterations affect the association of the metals in the area and some metals, such as $\mathrm{As}$ and $\mathrm{Bi}$, are good path-finders for $\mathrm{Au}$ [20]. This may indicate that $\mathrm{Au}$ is found in association with sulfide minerals rather than quartz veins. The major correlation for the $\mathrm{Cu}, \mathrm{Pb}, \mathrm{Zn}, \mathrm{Sn}, \mathrm{Mo}$ and $\mathrm{W}$ components indicate that their association was with the sulfide veins. Negative correlations were observed for $\mathrm{Au}$ with $\mathrm{Pb}, \mathrm{Sn}$, Mo, $\mathrm{Li}$ and $\mathrm{Bi}$; As with $\mathrm{Cu}, \mathrm{Pb}, \mathrm{Zn}$ and $\mathrm{Li}$; $\mathrm{Cu}$ with $\mathrm{Mo}$, $\mathrm{Bi}$ and $\mathrm{W}$; $\mathrm{Pb}$ with $\mathrm{Sn}$, Mo and $\mathrm{Bi}$; Mo with $\mathrm{Li}$; $\mathrm{Li}$ with $\mathrm{W}$ and Bi with $\mathrm{W}$ (Table 2(a)). These results indicate that the analysis of the metals is not linked with each other. Furthermore, these metals have different natural sources such as hydrothermal alteration, quartz veins and pegmatite dyke depending upon the area under study. 
Table 1. Lithology and petrography of the rock samples of the study.

\begin{tabular}{|c|c|c|}
\hline Sample number & Lithology & Petrography \\
\hline $1,2,20$ & $\begin{array}{l}\text { Aplite granite with } \\
\text { highly crashed rocks } \\
\text { affected by alteration }\end{array}$ & $\begin{array}{l}\text { Granite rock fragments composed of quartz, feldspar, and biotite. } \\
\text { Highly fractured crystals of feldspar, quartz, hornblende and epidote. } \\
\text { Hornblende occurs in clots giving the rock a mottled appearance. } \\
\text { The cemented material consists of calcite and very fine } \\
\text { grains of quartz or cryptocrystalline. Quartz was partially } \\
\text { metamorphosed to quartzite. }\end{array}$ \\
\hline 3,26 & $\begin{array}{l}\text { Alteration granite, fine to } \\
\text { medium grain size, mineral } \\
\text { composition quartz, feldspar } \\
\text { and biotite, with calcite } \\
\text { veins associated } \\
\text { in the alteration zone }\end{array}$ & $\begin{array}{l}\text { Calcite minerals contain cavities filled with fibrous quartz and } \\
\text { opaque minerals. Calcite shows polysynthetic twinning and two } \\
\text { cleavage sets (rhomb cleavage). Silica occurs as cryptocrystalline } \\
\text { fibrous chalcedony and fine-grains filled the fractures and } \\
\text { spaces or voids. Micrographic textures are visible. Iron oxides occur } \\
\text { surrounding the voids or separated along the fractures. }\end{array}$ \\
\hline $\begin{array}{c}4,6,7,8,9 \\
10,11,34,60\end{array}$ & $\begin{array}{l}\text { The alteration zone } \\
\text { includes quartz veins } \\
\text { with highly crashed rocks }\end{array}$ & $\begin{array}{l}\text { The major textures evident are equigranular, interstitial perthitic } \\
\text { and poikilitic. Quartz occurs as anhedral and highly fractured crystals, } \\
\text { filling up the spaces between the plagioclase crystals. Feldspar occurs } \\
\text { as plagioclase, a major component and a few percent of perthite } \\
\text { with perthitic texture. More than } 40 \% \text { is plagioclase found as euhedral } \\
\text { and subhedral prisms showing zoning and polysynthetic twinning. } \\
\text { It is highly weathered and altered to calcite and sericite. Biotite } \\
\text { is rare and highly weathered having been altered to iron oxides. }\end{array}$ \\
\hline $\begin{array}{c}12,13,14, \\
15,16,17, \\
18,19,23, \\
29,30,31,33\end{array}$ & $\begin{array}{l}\text { Thin Quartz veins } \\
\text { (2 - } 5 \mathrm{~cm} \text { in thickness), } \\
\text { showing a high degree of } \\
\text { alteration and crashed rocks, } \\
\text { and trace minerals, } \\
\text { like } \mathrm{Cu} \text { and } \mathrm{Pb}\end{array}$ & $\begin{array}{l}\text { The major texture is equigranular and spherulitic. It consists of } \\
\text { euhedral elongated crystals of quartz and orthoclase as the major } \\
\text { minerals due to the intergrowth between quartz and feldspar like } \\
\text { a sheaf form. The slide shows cryptocrystalline silica as a banded } \\
\text { rock from the veins, thin veins of cryptocrystalline and spherulitic } \\
\text { chalcedony associated with sericite and calcite, fine-grained } \\
\text { quartz and finally cryptocrystalline and fibrous chalcedony } \\
\text { associated with sericite. A few crystals of orthoclase partially altered } \\
\text { and sericite. Iron oxides occur as accessories as very fine aggregates. }\end{array}$ \\
\hline 21 & $\begin{array}{l}\text { Applite granite with } \\
\text { green color and alteration }\end{array}$ & $\begin{array}{l}\text { The slide shows felsitic rock composed of feldspar and } \\
\text { quartz crystals. The feldspars are altered to sericite and } \\
\text { kaolin minerals. Biotite occurs as rare mineral and is altered to chlorite. }\end{array}$ \\
\hline 22,59 & $\begin{array}{l}\text { Quartz veins with the } \\
\text { secondary green color } \\
\text { of the minerals }\end{array}$ & $\begin{array}{l}\text { Graphic texture is observed. The biotite xenocrysts are partially } \\
\text { altered to chlorite and iron oxides. Iron oxides and black spots } \\
\text { occur as accessories and separated randomly in the groundmass. }\end{array}$ \\
\hline $24,32,27,28$ & $\begin{array}{l}\text { Basaltic dyke cutting } \\
\text { the granite host rocks, } \\
\text { with quartz veins }\end{array}$ & $\begin{array}{l}\text { This slide shows two types of rock composition, the first being } \\
\text { andesite rock. It consists of feldspar and glass. } \\
\text { The feldspar (plagioclase) occurs as small laths and shows } \\
\text { twinning and zoning. It is predominantly trachytic in texture. } \\
\text { It contains black materials which could be volcanic glass or } \\
\text { opaque minerals. The second type comprises chalcedony veins } \\
\text { cutting the andesite rock. Spherulitic texture is predominant } \\
\text { in the dyke and consists of a dense mass of very intergrown quartz } \\
\text { and alkali feldspar (orthoclase) needles, radiating from } \\
\text { a common nucleus. These spherulites are followed by } \\
\text { fine-grained quartz presenting a drusy structure followed by } \\
\text { calcite mineral in the middle (forming bands). This dyke is rich } \\
\text { in opaque and fine accumulated band-like aggregates } \\
\text { separated from the beginning of the dyke to its end. }\end{array}$ \\
\hline 35 & $\begin{array}{l}\text { Granodiorite, composite of mafic } \\
\text { minerals feldspar, Biotite and } \\
\text { hornblende }\end{array}$ & $\begin{array}{l}\text { Granular, consertal and poikilitic textures predominate. Anhedral } \\
\text { and highly fractured quartz crystals comprise about } 30 \% \text {. } \\
\text { Feldspar includes both the orthoclase and plagioclase forms. } \\
\text { Plagioclase constitutes more than } 45 \% \text { and occurs as euhedral } \\
\text { to subhedral prisms showing zoning and polysynthetic twinning. } \\
\text { It has been highly weathered and altered to clay and sericite. } \\
\text { Biotite occurs in about } 10 \% \text { of highly weathered rock, } \\
\text { altered to chlorite-like masses. }\end{array}$ \\
\hline
\end{tabular}




\section{Continued}

36

37,5

39

Granite, coarse grain size, feldspar, quartz and Biotite constitute the main mineral compositions
Granular texture; metamorphic rock fragments of the Biotite Schist consisting of quartz, feldspar and biotite. Biotite was partially altered to chlorite and iron oxides; opaque minerals were seen associated with biotite. Crystals (phenocrysts) partially altered to sericite or clay especially at the centre. Feldspar crystals of fractured quartz are visible. All these rock fragments and xenoliths are cemented by fine-grained of quartz.

Equigranular and perthite texture is present. Quartz, perthite and orthoclase are the major minerals. Feldspars are altered to clay and biotite to sericite. Rare occurrences of altered muscovite. Opaque minerals as accessories occur as very fine aggregates.

Phenocrysts of zoned plagioclase are altered to kaolin. Cryptocrystalline silica dust is present as cemented material or as veins. Opaque minerals occur as accumulated aggregates.

The major textures are granular, consertal and poikilitic, consisting of quartz with anhedral crystals and the highly fractured forms constitute about $20 \%$. In some places they occur as clots (fine-grained) between the coarse crystals. Biotite is altered to iron oxides.

The major textures include granular, consertal and poikilitic. It consists of quartz: it occurs as anhedral crystals and highly fractured crystals forming about $40 \%$. Feldspar occurs as perthite and shows perthitic texture, is altered to clay forming more than $30 \%$, while the plagioclase forms about $25 \%$. It occurs as euhedral to subhedral prisms showing zoning and polysynthetic twinning. It is highly weathered and altered to clay and sericite. Biotite forms less than $3 \%$ and is highly weathered and altered to iron oxides. Iron oxides occur as veins due to a solution rich in Fe.

Micrographic texture is evident. It consists of fine-grained quartz and orthoclase as the major minerals associated with each other. Plagioclase occurs as a minor mineral. Orthoclase and plagioclase are altered to kaolin and sericite. Biotite occurs in a low percentage, partially altered to chlorite. Iron oxides and calcite occur as secondary minerals filling the fractures and veins. The fractures show a dendritic texture. Phenocrysts of fractured quartz are present.

The major textures are intergranular, consertal and poikilitic. It consists of about 30\% quartz with highly fractured anhedral crystals. Feldspar occurs as both perthite and plagioclase. Plagioclase occurs as euhedral to subhedral prisms showing polysynthetic twinning It has been highly weathered and altered to calcite, clay (kaolin) with sericite as the rim. Perthite occurs as coarse-grained and is perthitic in texture with Carlsbad twinning. Mica sheets (biotite and muscovite) form about 5\% and are highly weathered and altered to chlorite and iron oxide like masses. Calcite and iron oxides occur as secondary minerals filling fractures and veins. Opaque minerals occur as accumulated aggregates or masses while zircon occurs as an inclusion in the mica sheet.

The geochemical anomaly map for the rock samples of $\mathrm{Au}, \mathrm{As}, \mathrm{Cu}, \mathrm{Pb}, \mathrm{Sn}, \mathrm{Mo}, \mathrm{Bi}, \mathrm{W}, \mathrm{Zn}$ and $\mathrm{Li}$ are shown in Figure 3. Four geochemical areas of anomalies are represented in the geochemical anomaly area map Figure 5(a). The anomalous areas are concentrated within the alteration and quartz veins. Strong geochemical anomalous areas for $\mathrm{Au}$ overlapping $\mathrm{Cu}, \mathrm{As}, \mathrm{Sn}, \mathrm{Bi}, \mathrm{Mo}$ and $\mathrm{W}$ are those represented by the hydrothermal alteration zone [anomaly $1=($ Au value $50 \mathrm{ppb}$ overlap $\mathrm{Cu})$ and anomaly $2=$ Au value $50 \mathrm{ppb}$ overlap $\mathrm{As}+\mathrm{Sn}+\mathrm{Bi}+\mathrm{Mo}+$ $\mathrm{W}$ ], anomaly 3 represented the pegmatite to rhyolite dyke [anomaly $3=\mathrm{W}$ overlap $\mathrm{Zn}+\mathrm{Li}$ ), and anomaly 4 showed a high degree of alteration and crashed rocks, with trace $\mathrm{Cu}$ and $\mathrm{Pb}$ minerals]. The ore in anomaly area 2 ( $\mathrm{Au}, \mathrm{As}, \mathrm{Sn}, \mathrm{Cu}, \mathrm{Bi}, \mathrm{Mo}$ and $\mathrm{W}$ ) explains the presence of the ore minerals expected to occur, such as specularite, pyrrhotite, cassiterite, arsenopyrite, molybdenite, chalcopyrite, poor gold, sphalerite and wolframite and the alteration rocks were shown to have undergone albitization, sericitization and chloritization for rocks which often have a crisp wall [21] [22], (see petrography and mineralogy section). 

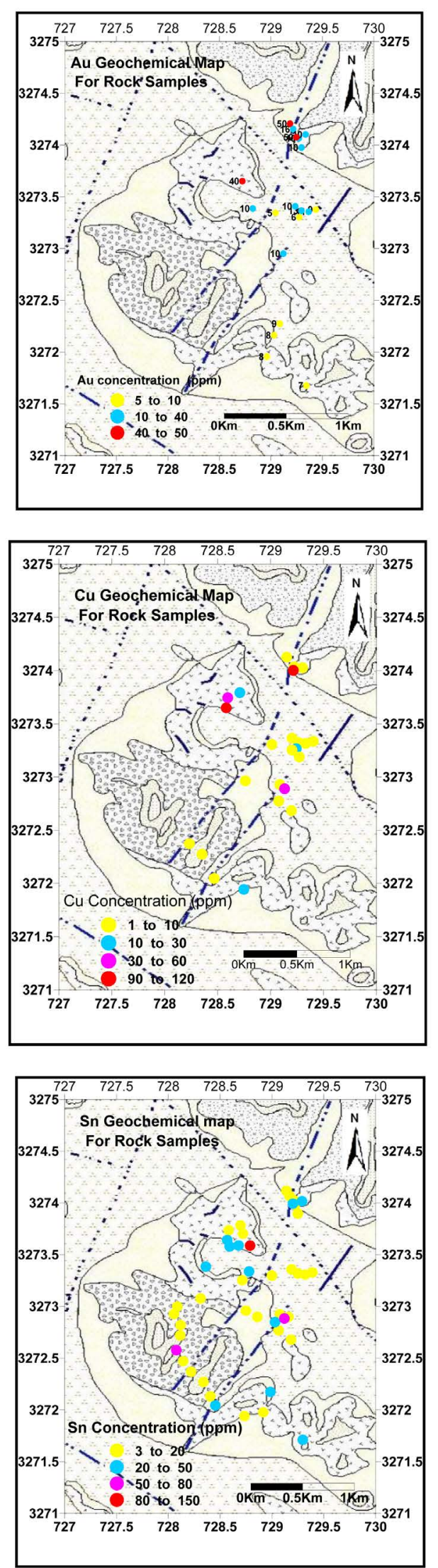
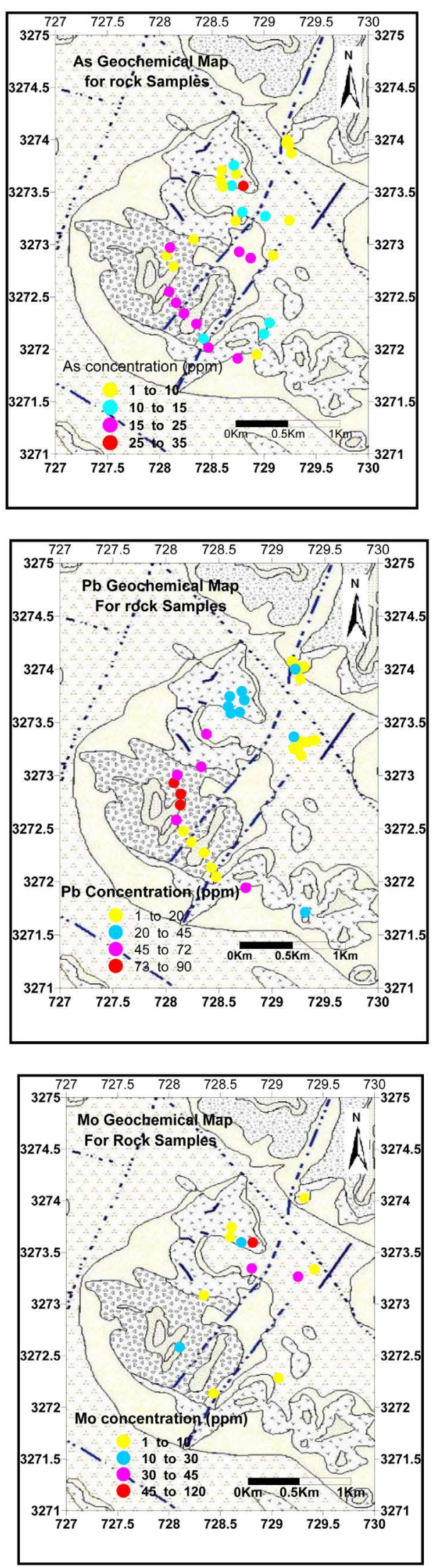

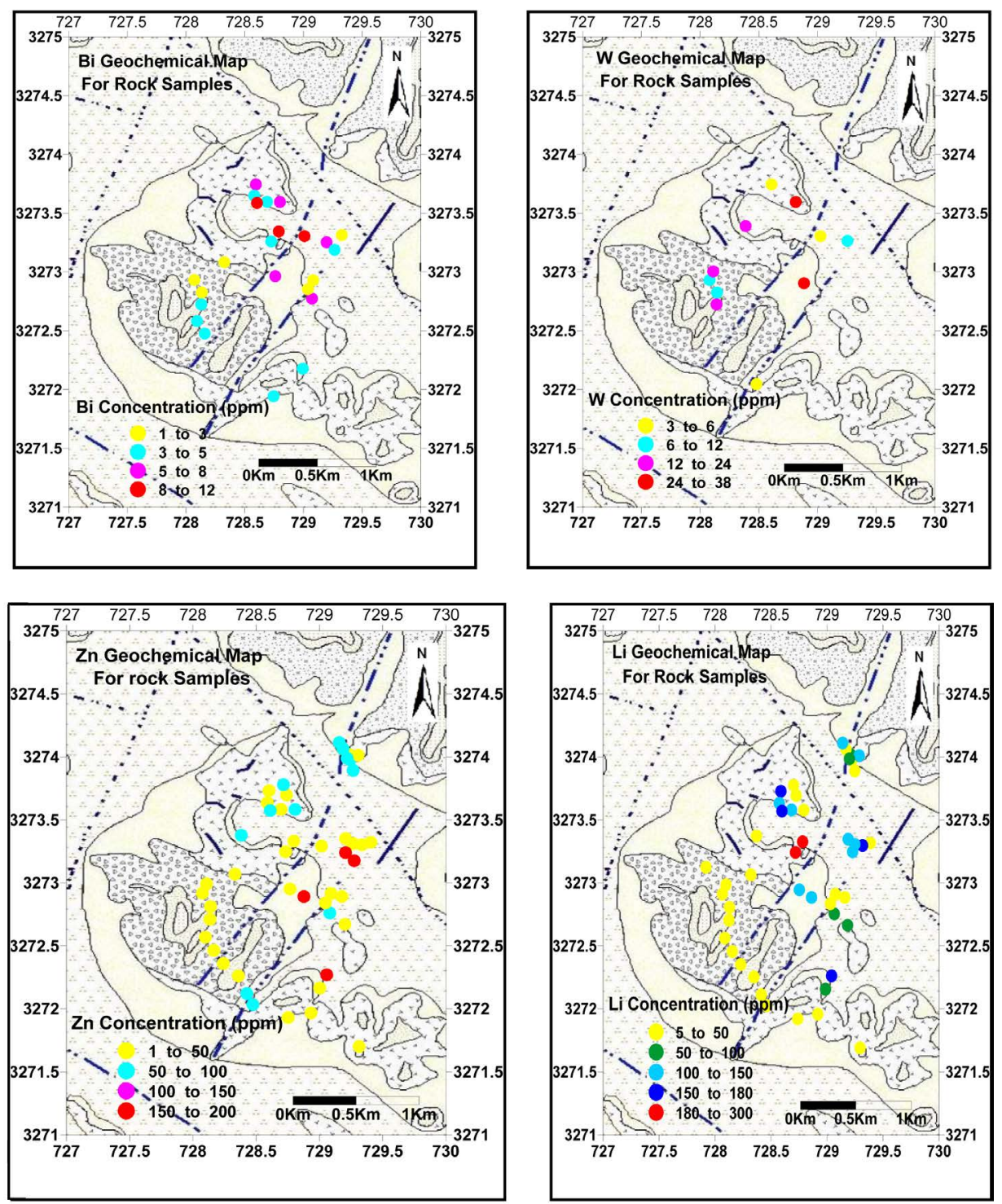

Figure 3. Geochemical map showing the distribution of ( $\mathrm{Au}, \mathrm{As}, \mathrm{Cu}, \mathrm{Pb}, \mathrm{Sn}, \mathrm{Mo}, \mathrm{Bi}, \mathrm{W}, \mathrm{Zn}, \mathrm{Li}$ ) in the rock samples.

\subsection{Heavy Mineral Geochemistry}

The heavy mineral (HM) method has been found to be more sensitive for detection and discovery in mineral exploration. This method has been in use for the last 100 years for exploration of gold by panning. The recent, heavy mineral surveys used the concentrates from the drainage sediment samples as beneficial geochemical and mineralogical guides to mineralization [23]. The collection of the large sample $>20 \mathrm{~L}$ and concentration of the desired minerals into small sub-samples was effective in the process of gold exploration. The production and analysis of the heavy minerals are yet to become popular as the common exploration methods to detect the anomalous areas. These methods have been successfully applied and used in the study of the granitoid rock cover in southwest Jordan. Using the stream sediment for the study of the geochemical heavy mineral samples was found to be the best method for geochemical surveys. It includes a wide variety of environments from large gravel bars in rivers or to tiny pools of sediment, in rock narrow creeks and to dry washes in arid climates. The sample site selected for bars showed the presence of sand and gravel because the concentration of heavy minerals typically occurs in these specific areas. The best heavy mineral samples collected from the silt or clay particles from quiet water sedimentation or high-energy environments within the sediments provided the best material. The sample 
Table 2. (a) Statistical analysis data for the rock samples; (b) Correlation matrix of the trace elements for rock samples.

(a)

\begin{tabular}{ccccccccccc}
\hline & $\begin{array}{c}\mathrm{Au} \\
(\mathrm{mg} / \mathrm{ton})\end{array}$ & $\begin{array}{c}\mathrm{As} \\
(\mathrm{ppm})\end{array}$ & $\begin{array}{c}\mathrm{Cu} \\
(\mathrm{ppm})\end{array}$ & $\begin{array}{c}\mathrm{Pb} \\
(\mathrm{ppm})\end{array}$ & $\begin{array}{c}\mathrm{Sn} \\
(\mathrm{ppm})\end{array}$ & $\begin{array}{c}\mathrm{Mo} \\
(\mathrm{ppm})\end{array}$ & $\begin{array}{c}\mathrm{Bi} \\
(\mathrm{ppm})\end{array}$ & $\begin{array}{c}\mathrm{W} \\
(\mathrm{ppm})\end{array}$ & $\begin{array}{c}\mathrm{Zn} \\
(\mathrm{ppm})\end{array}$ & $\begin{array}{c}\mathrm{Li} \\
(\mathrm{ppm})\end{array}$ \\
\hline $\begin{array}{c}\text { Number of values } \\
\text { Minimum }\end{array}$ & 19 & 35 & 27 & 35 & 46 & 13 & 24 & 11 & 49 & 48 \\
$\quad$ Maximum & 5 & 1 & 1 & 1 & 3 & 2 & 1 & 3 & 1 & 5 \\
$\quad$ Mean & 50 & 32 & 120 & 82 & 150 & 50 & 10 & 36 & 200 & 198 \\
$\quad$ Median & 15.4 & 11.7 & 22.63 & 31.2 & 22.85 & 15.8 & 4.1 & 12.7 & 56.8 & 67.4 \\
$\quad$ Average & 10 & 10 & 5 & 25 & 17 & 9 & 3 & 9 & 42 & 42.5 \\
Standard deviation & 15.37 & 11.74 & 22.63 & 31.23 & 22.85 & 15.76 & 4.1 & 12.73 & 56.8 & 67.4 \\
Threshold 1 = mean + 2 SD & 44 & 26.98 & 97.03 & 73.23 & 82.86 & 48.8 & 8.9 & 34.1 & 153.08 & 184.74 \\
Threshold 2 = median + 2 SD & 38.6 & 25.28 & 79.4 & 75.6 & 68.66 & 42 & 7.8 & 30.4 & 138.28 & 159.84 \\
\hline
\end{tabular}

(b)

\begin{tabular}{|c|c|c|c|c|c|c|c|c|c|}
\hline & $\mathrm{Au}$ & As & $\mathrm{Cu}$ & $\mathrm{Pb}$ & Sn & Mo & $\mathrm{Zn}$ & $\mathrm{Li}$ & $\mathrm{Bi}$ \\
\hline $\mathrm{Au}$ & 1 & & & & & & & & \\
\hline As & 0.827 & 1 & & & & & & & \\
\hline $\mathrm{Cu}$ & 0.694 & -0.128 & 1 & & & & & & \\
\hline $\mathrm{Pb}$ & -0.019 & -0.032 & 0.833 & 1 & & & & & \\
\hline $\mathrm{Sn}$ & -0.178 & 0.156 & 0.093 & -0.088 & 1 & & & & \\
\hline Mo & -0.264 & 0.829 & -0.015 & -0.079 & 0.726 & 1 & & & \\
\hline $\mathrm{Zn}$ & 0.057 & -0.040 & 0.0285 & 0.340 & 0.269 & 0.007 & 1 & & \\
\hline $\mathrm{Li}$ & -0.004 & -0.071 & 0.376 & 0.180 & 0.194 & -0.007 & 0.4 & 1 & \\
\hline $\mathrm{Bi}$ & -0.200 & 0.276 & -0.148 & -0.331 & 0.165 & 0.529 & 0.085 & 0.657 & 1 \\
\hline W & 1.000 & 0.675 & -0.413 & 0.696 & 0.032 & 0.967 & 0.706 & -0.041 & -0.030 \\
\hline
\end{tabular}

studies provided high-energy sediments in dry arid climates.

The geochemical data analysis for HM was treated to get the results of the geochemical statistics and maps of the geochemical anomalies Figure 4. The statistical treatment of the HM data resulted in the adoption of two threshold values (Threshold $1=$ mean +2 SD) and (Threshold $2=$ median +2 SD) respectively; the background values were equal to the mean value [19]. Thresholds 1 and 2 for $\mathrm{Au}=22.52 \& 21.91, \mathrm{As}=30.20 \& 28.24, \mathrm{~Pb}=$ $121.84 \& 122.40, \mathrm{Sn}=120.64 \& 123.40, \mathrm{Bi}=47.60 \& 49.80, \mathrm{~W}=76.70 \& 73.00, \mathrm{Zn}=333.48 \& 330.48$, and $\mathrm{Li}=47.20 \& 45.20$, respectively (Table 3). The Pearson's correlation coefficients for the HM data showed low positive linear correlations among the concentrations of Au with As, Zn, Li, and negative linear correlations Au for $\mathrm{Pb}, \mathrm{Sn}, \mathrm{Bi}$ and $\mathrm{W}$. Moderate positive correlation of the $\mathrm{Pb}$ with $\mathrm{Zn}$ and $\mathrm{Li}(\mathrm{r}=0.58$ and 0.56 ), $\mathrm{Bi}$ with $\mathrm{W}$ ( $\mathrm{r}=$ 0.6), W with Li ( $r=51)$ Table 4. These correlations revealed that the hydrothermal alterations affected the study area and the associations of some metals with sulfide were weathered to the stream sediment like $\mathrm{Pb}$ and $\mathrm{Zn}$; but Li sources, suggest the pegmatite dyke crossing the area and some metals such as Bi are good path-finders for $\mathrm{Au}[20]$.

The geochemical anomaly map for the HM samples of $\mathrm{Au}, \mathrm{As}, \mathrm{Pb}, \mathrm{Sn}, \mathrm{Bi}, \mathrm{W}, \mathrm{Zn}$ and Li is shown in Figure 5. Four geochemical anomaly areas are documented in Figure 5(b). The anomalous areas were concentrated within the stream crossing the alteration zone, quartz veins and pegmatite dyke. The anomaly area 1 for Au overlaps with the $\mathrm{Au}+\mathrm{Cu}$ anomaly for the rock samples; anomaly area 2 for $\mathrm{Sn}+\mathrm{Pb}+\mathrm{Zn}+\mathrm{W}+\mathrm{Li}$ overlaps anomaly area 2 for the rock samples. The anomalous areas 3 and 4 represented the areas in the downstream. These re- 

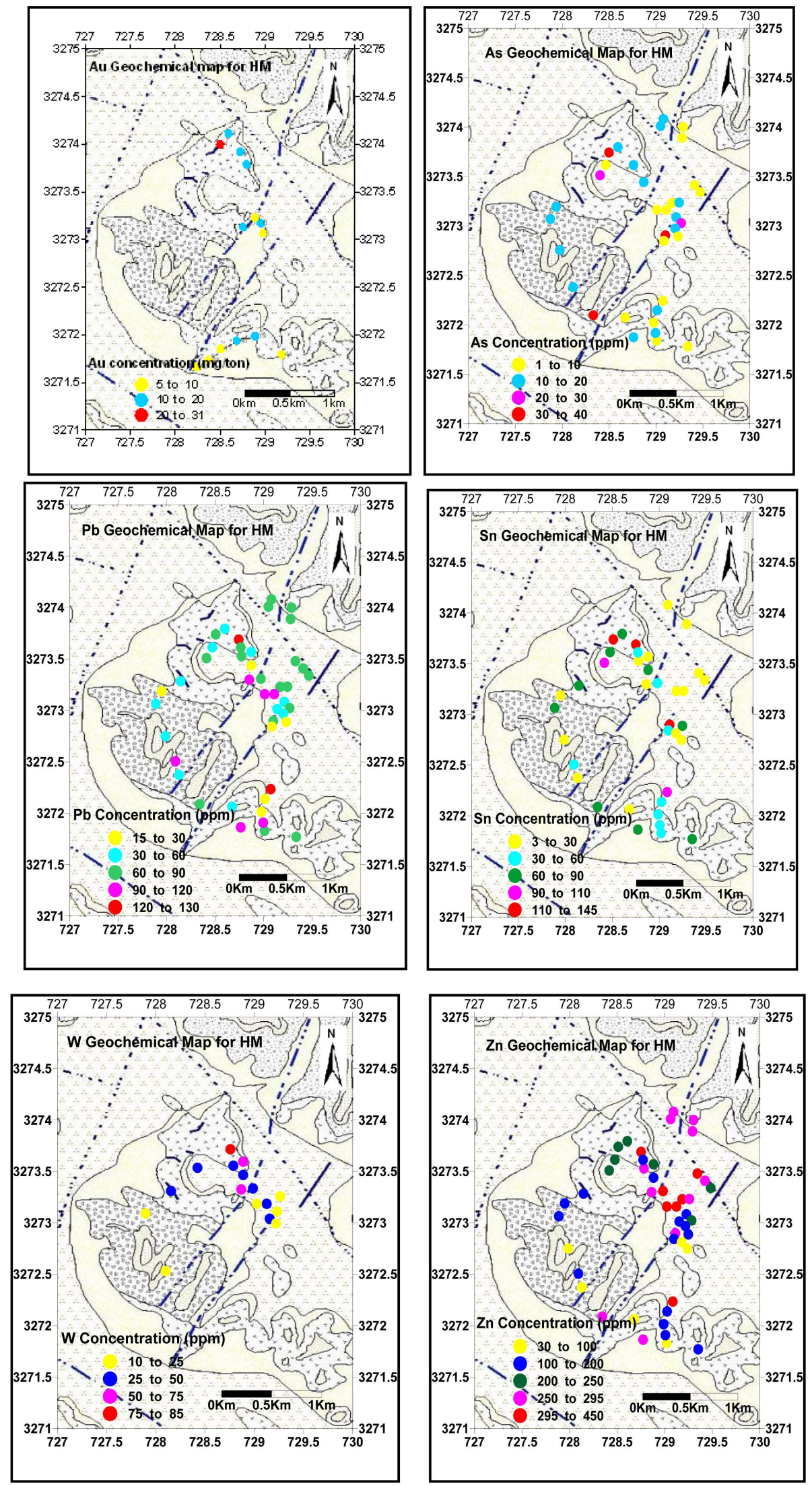

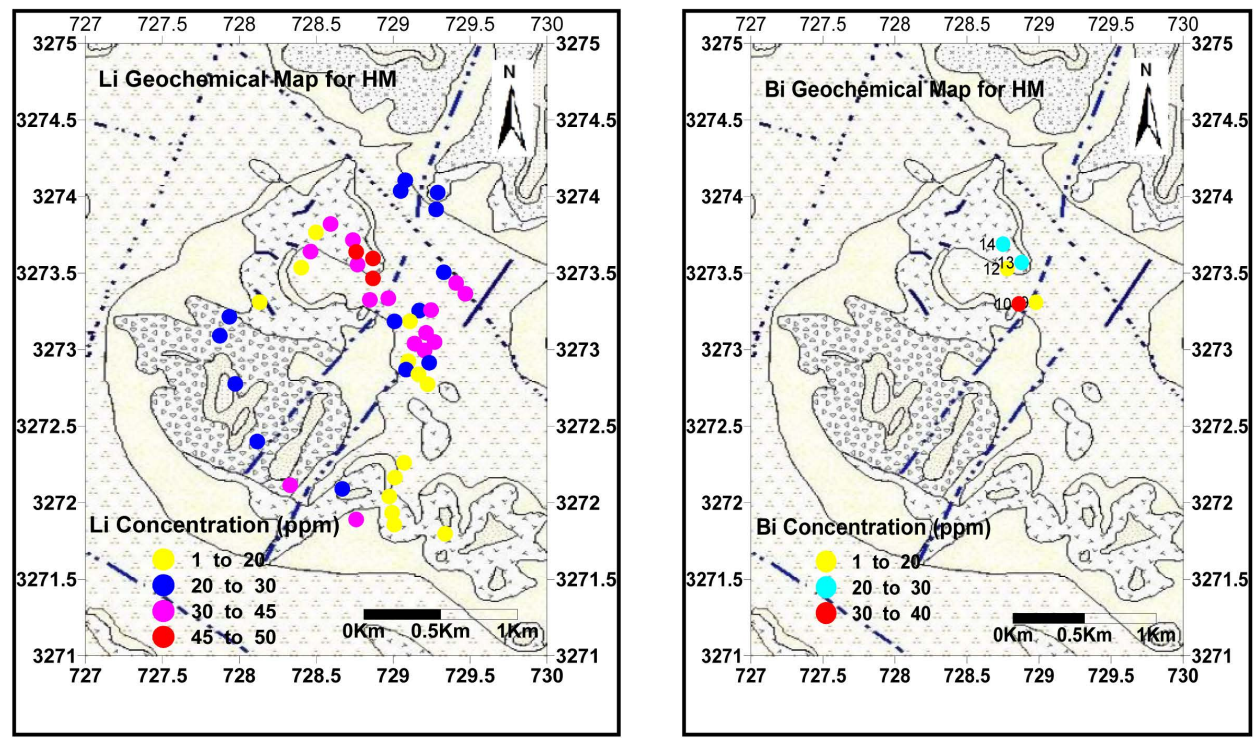

Figure 4. Geochemical map showing the distribution of ( $\mathrm{Au}, \mathrm{As}, \mathrm{Pb}, \mathrm{Sn}, \mathrm{W}, \mathrm{Zn}, \mathrm{Li}$ and $\mathrm{Bi}$ ) for heavy mineral samples.

Table 3. Statistical analysis data for heavy mineral samples.

\begin{tabular}{cccccccccc}
\hline & $\mathrm{Au}(\mathrm{mg} / \mathrm{ton})$ & $\mathrm{As}(\mathrm{ppm}$ & $\mathrm{Pb}(\mathrm{ppm})$ & $\mathrm{Sn}(\mathrm{ppm})$ & $\mathrm{Bi}(\mathrm{ppm})$ & $\mathrm{W}(\mathrm{ppm})$ & $\mathrm{Zn}(\mathrm{ppm})$ & $\mathrm{Li}(\mathrm{ppm})$ \\
\hline Number of values & 14 & 46 & 44 & 37 & 5 & 17 & 39 & 45 \\
Minimum & 5 & 1 & 15 & 3 & 4 & 9 & 38 & 10 \\
Maximum & 30 & 37 & 123 & 140 & 38 & 82 & 292 & 49 \\
$\quad$ Mean & 10.6 & 13.00 & 64.34 & 48.24 & 21.80 & 34.70 & 193.60 & 26.00 \\
Median & 10 & 11.00 & 65.00 & 51.00 & 24.00 & 31.00 & 190.00 & 24.00 \\
Average & 10.64 & 12.97 & 64.34 & 48.24 & 21.80 & 54.71 & 193.61 & 26.04 \\
$\quad$ Standard deviation & 5.96 & 8.62 & 28.75 & 36.20 & 12.90 & 21.00 & 69.94 & 10.60 \\
Threshold 1 = mean + 2SD & 22.52 & 30.20 & 121.84 & 120.64 & 47.60 & 76.70 & 333.48 & 47.20 \\
Threshold 2 = median + 2SD & 21.91 & 28.24 & 122.50 & 123.40 & 49.80 & 73.00 & 330.48 & 45.20 \\
\hline
\end{tabular}

Table 4. Correlation Matrix for samples of heavy minerals.

\begin{tabular}{cccccccc}
\hline $\mathrm{HM}$ & $\mathrm{Au}$ & $\mathrm{As}$ & $\mathrm{Pb}$ & $\mathrm{Sn}$ & $\mathrm{Bi}$ & $\mathrm{W}$ & $\mathrm{Zn}$ \\
\hline $\mathrm{Au}$ & 1 & & & & & & \\
$\mathrm{As}$ & 0.39 & 1 & & & & & \\
$\mathrm{~Pb}$ & -0.01 & 0.08 & 1 & & & & \\
$\mathrm{Sn}$ & -0.19 & 0.49 & 0.27 & 1 & & & \\
$\mathrm{Bi}$ & -0.30 & 0.44 & 0.22 & 0.16 & 1 & & \\
$\mathrm{~W}$ & -0.30 & 0.48 & 0.26 & 0.09 & 0.60 & & \\
$\mathrm{Zn}$ & 0.01 & 0.20 & 0.58 & 0.29 & -0.04 & 0.46 & \\
$\mathrm{Li}$ & 0.02 & 0.20 & 0.56 & 0.02 & -0.05 & 0.51 & 0.17 \\
\hline
\end{tabular}




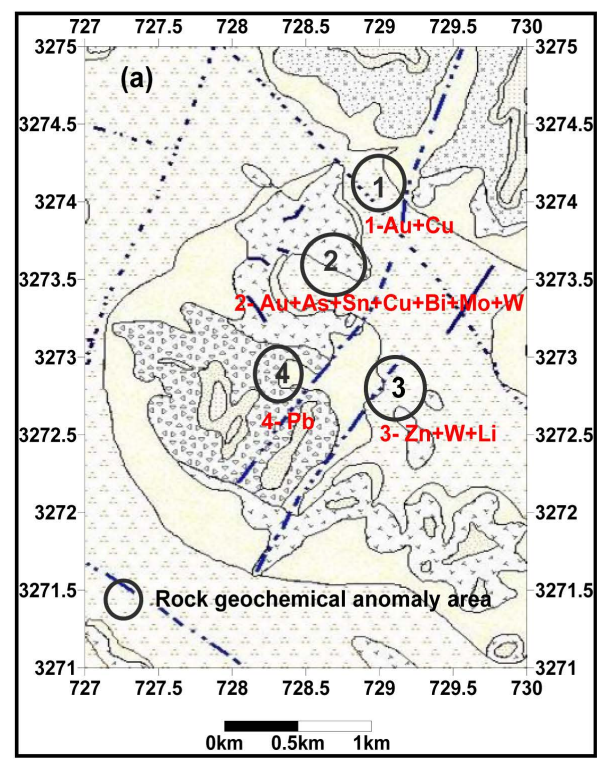

(a)

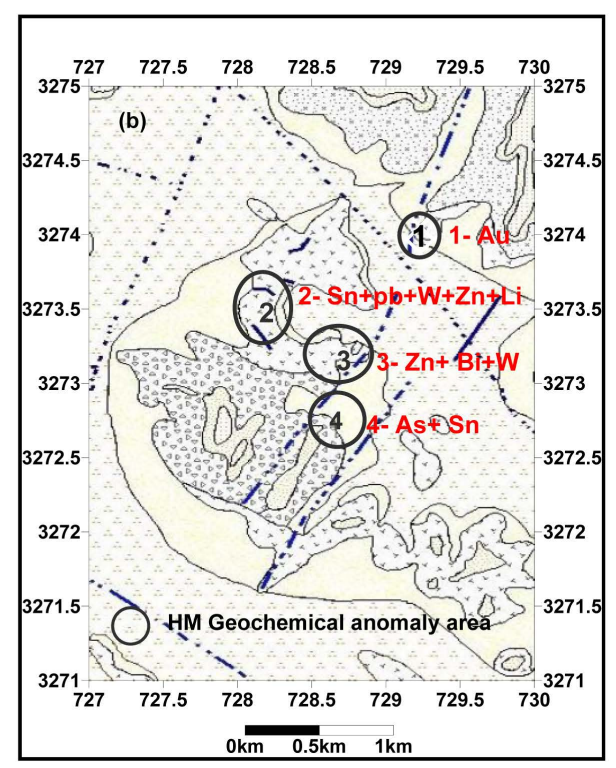

(b)

Figure 5. Geochemical anomalous elements area map for (a) rock and (b) heavy mineral samples.

vealed the association of the metals in alteration with the host rocks and accumulated within the sediment deposits. According to [24], the exploration for gold (105 ppb for HM and $200 \mathrm{ppb}$ in the quartz veins) in the same granitoid unit of the the wadi Al Marsad area, have been documented as having the possible occurrence of gold in the area under study.

\section{Conclusion}

Detailed geochemical investigations of the rock and stream sediments for the HM samples were done during the geochemical exploration for the study area. High background values of metals at a hydrothermal alteration zone have been discovered, naturally. The discovery of the south Wadi Rumman area prospect during the following up of an already delineated anomaly has been a successful exploration using rock and $<1 \mathrm{~mm}$ heavy mineral sediment geochemistry. Moreover, the sampling technique was proven to be a very sensitive exploration tool even in the discovery of small-scale mineralization, in areas having well-developed drainage, as in the Wadi Rumman area. Identification and sampling of the altered and mineralized rocks, which floated in the streams, were critical in categorizing the details of the geochemical results [25]. Rock sampling effectively delineated the ÓAu-overlapping $\mathrm{Cu}, \mathrm{As}, \mathrm{Sn}, \mathrm{Bi}, \mathrm{Mo}$ and $\mathrm{W}$ geochemical anomaly. The geochemical signatures of Au and As in the Wadi Rumman appear to be hydrothermal alterations, quartz veins and pegmatite dykes, respectively. Effective Heavy Mineral sampling and delineated Au geochemical anomaly of area 1 specificities with the rock geochemical anomaly of area 1 , and no negate Au were investigated in the study samples.

\section{Acknowledgements}

The author is thankful to the Natural Resources Authority for assistance in geochemical analysis and to ICPAES and (AAS) for their contribution to the project "Detailed Geochemical Prospecting Minerals for Proterozoic granitoids, Southwest Jordan". The author is indebted and grateful to the anonymous reviewers for their comments and assistance in improving the manuscript quality.

\section{References}

[1] Vladimir, K., Esa, S., Pavel, S. and Erik, T. (2000) Gold Geochemistry and Mineralogy of Till Fines: A New Approach for Data Integration. Bulletin of the Geological Society of Finland, 72, Parts 1-2, 57-69.

[2] Rashdan, M. (1988) The Regional Geology of Aqaba-Wadi Araba Area. Bull No. 7. Geology Director. Natural Resources Authority, Amman. 
[3] Jarrar, G., Wachendorf, H. and Zellmer H. (1991) The Saramuj Conglomerate: Evolution of a Pan-African Molasse Sequence from Southwest Jordan. Neues Jahrbuch fur Mineraloggie and Palaeontogie, 335-356.

[4] McCourt, W. and Ibrahim, K. (1990) The Geology, Geochemistry and Tectonic Setting of the Granite and Associated Rocks in the Aqaba and Araba Complexes of Southwest Jordan. Bull. 10, Geology Director, Natural Resources Authority, Amman.

[5] Ibrahim, K.M. and McCourt, W.J. (1995) Neoproterozoic Granite Magmatism and Tectonic Evolution of the Northern Arabian Shield, Evidence from Southwest Jordan, Journal African Earth Sciences, 20, 103-118. http://dx.doi.org/10.1016/0899-5362(95)00037-T

[6] Jarrar, G., Wachendorf, H. and Zachmann, D. (1993) A Pan-African Alkaline Pluton Intruding the Sarmouj Conglomerate Southwest Jordan. Geologische Rundschau, 82, 121-135. http://dx.doi.org/10.1007/BF00563275

[7] Jarrar, G., Stern, R.J., Saffarini, G. and Al-Zubi, H. (2003) Late and Post Orogenic Neoproterozoic Intrusion of Jordan: Implication for Crustal Growth in the Northernmost Segment of the East African. Orogen Precambrian Research, 23, 295-319. http://dx.doi.org/10.1016/S0301-9268(03)00073-1

[8] Rabba, I. and Ibrahim, K. (1988) Petrography of the Plutonic Rocks of the Aqaba Complex. Bull No. 9. Geology Director, Natural Resources Authority, Amman.

[9] Abdulhamid, G. (1986) Geological Map Jabal Um Ishrin (Wadi Rum), Scale 1:50,000. Natural Resources Authority, Geological Directorate, Amman.

[10] Abdulhamid, G. (1990) The Geology of Jabal Umm Ishrin Area (Wadi Rum), Map Sheet No. 3049II. Bulletin 14, Natural Resources Authority, Geological Directorate. Map Division, Amman.

[11] Bender, F. (1974) Geology of the Arabian Peninsula, Jordan. US Geological Survey Professional Paper, 36, 1-560.

[12] Barjous, M. (1987) Structural Study of the Area between Petra an Ash Shawbak. MSC. Theses, University of Jordan, Amman.

[13] Clark, M.D. (1985) Late Proterozoic Crustal Evolution of the Midyan Region, Northwestern Saudi Arabia. Geology, 13, 611-615. http://dx.doi.org/10.1130/0091-7613(1985)13<611:LPCEOT>2.0.CO;2

[14] Meier, A.L. (1980) Flameless Atomic-Absorption Determination of Gold in Geological materials. Journal of Geochemical Exploration, 13, 77-85. http://dx.doi.org/10.1016/0375-6742(80)90022-9

[15] NRA and BRGM PROJECT Staff (1994) Geochemical and Mineral Exploration of Araba-Aqaba Complex-Final report. NRA, Amman, 209.

[16] Al-Hwaiti, M., Zoheir, B., Lehmann, B. and Rabba, I. (2010) Epithermal Gold Mineralization at Wadi AbuKhushayba, Southwestern Jordan. Ore Geology Reviews, 38, 101-112. http://dx.doi.org/10.1016/j.oregeorev.2010.07.002

[17] Wang, X.Q., Xie, X.J., Cheng, Z.Z. and Liu, D.W. (1999) Delineation of Regional Geochemical Anomalies Penetrating through Thick cover in Concealed Terrains-A Case History from the Olympic Dam Deposit, Australia. Journal of Geochemical Exploration, 66, 85-97. http://dx.doi.org/10.1016/S0375-6742(99)00036-9

[18] Levinson, A.A. (1974) Introduction to Exploration Geochemistry. Applied Publishing Ltd., Wilmette.

[19] Rose, A.W., Hawks, H.E. and Webb, J.H. (1979) Geochemistry in Mineral Exploration. Academic Press, New York.

[20] Anne, T., Pertti S. and Helena H. (2015) Gold Exploration Using Heavy Minerals in Till and Weathered Bedrock in Petäjäselkä, Northern Finland. Geochemistry: Exploration, Environment, Analysis, 15, 205-221. http://dx.doi.org/10.1144/geochem2014-288

[21] Anthony, M. (1993) Ore Geology and Industrial Minerals an Introduction. 3rd Edition, Blackwell Publishing, Malden, 389.

[22] Marcondes, L.C., Romulo, S. and Newton, C. (1999) The Geochemical Association Au-As-B-Cu-Sn-W in Latosal, Colluviums, Lateritic Iron Crust and Gossan in Carajas, Brazil: Importance for Primary Ore Identification. Journal of Geochemical Exploration, 67, 33-49. http://dx.doi.org/10.1016/S0375-6742(99)00065-5

[23] Bill, G. and Geo, P. (2015) Discovery Mineral Exploration Consultants. info@discoveryconsultants.com

[24] Al-Dalo Abdul, R. and Bany Yaseen, I. (2007) Geochemical Exploration for Gold and Minerals of Northern Wadi El Marsad Area, Natural Resources Authority, Geochemistry Division, Amman.

[25] Hseyun, Y. (2007) Stream Sediment Geochemical Exploration for Gold in the KazdaÛ Dome in the Biga Peninsula, Western Turkey. Turkish Journal of Earth Sciences, 16, 33-55. 